\title{
Efektivitas Program Pengembangan Usaha Agribisnis Perdesaan di Kabupaten Lampung Selatan
}

\author{
Effectiveness of Rural Agribusiness Development Program \\ in South Lampung Regency
}

\section{Rio Caesarion ${ }^{\star 1}$, Nora H. Pandjaitan ${ }^{\# 2}$ dan Muhammad Syamsun ${ }^{\# 3}$}

${ }^{1}$ Kementerian Pertanian RI

Gd B It. 3 Inspektorat IV, Jl. Harsono RM. No. 3 Ragunan, Pasar Minggu, Jakarta 12550

${ }^{2}$ Departemen Teknik Sipil dan Lingkungan, Fakultas Teknologi Pertanian, Institut Pertanian Bogor

${ }^{3}$ Departemen Manajemen, Fakultas Ekonomi dan Manajemen, Institut Pertanian Bogor

\#JI. Kamper, Kampus IPB Darmaga, Bogor 16680

\begin{abstract}
ABSTRAK
Pendapatan daerah per kapita di Kabupaten Lampung Selatan pada tahun 2008 sekitar Rp7.260.902, tetapi tahun 2009 meningkat menjadi Rp8.620.637. Kondisi ini belum mampu mengatasi kemiskinan dan menciptakan lapangan kerja yang memadai di daerah pedesaan, khususnya di Kabupaten Lampung Selatan. Saat ini Kabupaten Lampung Selatan menjadi salah satu daerah sasaran untuk program Pengembangan Usaha Agribisnis Perdesaan (PUAP). Pada tahun 2008 PUAP disalurkan Rp3.492.040.000 untuk 35 Gabungan Kelompok Tani (Gapoktan) dan tahun 2009 dibagikan 3.898.324.000 untuk 39 Gapoktan. Tujuan penelitian ini untuk menganalisis efektivitas PUAP di Kabupaten Lampung Selatan. Kesesuaian perencanaan hingga pelaksanaan kegiatan pertanian, pengembangan agribisnis pedesaan, pengembangan keuangan mikro, dan kegiatan mentoring. Penelitian ini menggunakan metode survei dengan bantuan kuesioner dan wawancara langsung kepada 86 responden anggota Gapoktan di Kabupaten Lampung Selatan. Analisis dilakukan dengan analisis regresi linear berganda. Hasil analisis menunjukkan bahwa setelah menerima PUAP, kinerja pertanian usaha kecil di Kabupaten Lampung Selatan menjadi lebih efektif, yang ditunjukkan dengan distribusi dan pemanfaatan bantuan tepat dengan perencanaan pertumbuhan bisnis pertanian, diversifikasi produk pertanian, modal kelompok meningkat, serta peran penyuluhan dalam Pelengkap dan Penyelia Mitra Tani (PMT) untuk membimbing kelompok.
\end{abstract}

Kata kunci: efektivitas, Gapoktan, kinerja, PUAP, usaha kecil

\section{ABSTRACT}

Income regional per capita in South Lampung regency of Lampung Province in 2008 only about Rp 7.260.902, but in 2009 had increased to Rp8.620.637. This condition had not been able to overcome poverty and create sufficient jobs in rural areas, particularly in South Lampung regency. According in this condition South Lampung Regency became one of the target area for Rural Agribusiness Development Program (PUAP). In 2008 PUAP was distributed Rp3.492.040.000 to 35 Gapoktan and in 2009 was distributed 3.898.324.000 to 39 Gapoktan. The objective of this study is to analyze the effectiveness of PUAP in South Lampung regency. Suitability of planning to the implementation of farm activities; rural agribusiness development; microfinance development, and mentoring activities. This study used survey methods and data were collected by questionnaires and direct interviews to 86 respondens member of Gapoktan in South Lampung regency. Analysis was conducted using multiple linear regression analysis. The direct result showed that after receiving PUAP, performance of small business agriculture in South Lampung regency became more effective. It was showed by distribution and utilization of assistance appropriate with the planning agricultural business growth, diversification of agricultural products, group capital increased and also role of extension in Complementary and PMT to guide the group.

Key words: effectiveness, Gapoktan, performance, PUAP, small business

\footnotetext{
$\left.{ }^{\star}\right)$ Korespondensi:

Kementerian Pertanian Gd B It. 3 Inspektorat IV, JI. Harsono RM. No. 3 Ragunan, Pasar Minggu, Jakarta 12550; e-mail: caesarion2012@gmail.com
} 


\section{PENDAHULUAN}

Pada tahun 2008 pendapatan regional per kapita mencapai Rp7.260.902, sedangkan tahun 2009 terjadi kenaikan menjadi Rp8.620.637, atau terjadi kenaikan 18,73\% (BPS Kabupaten Lampung Selatan, 2010a). Dari tingkat pencapaian pendapatan regional masyarakat tersebut, bidang usaha kecil sektor pertanian memberikan kontribusi sangat besar untuk peningkatan pendapatan masyarakat Kabupaten Lampung Selatan, dengan jumlah kontribusi $49,83 \%$. Hal ini berarti sebagian besar masyarakat Lampung Selatan bekerja pada sektor pertanian (BPS Kabupaten Lampung Selatan, 2010a).

Sebagai salah satu sentra produksi padi di Provinsi Lampung, Kabupaten Lampung Selatan pada tahun 2009 dengan luas areal panen 77.059 ha, telah menghasilkan produksi padi 386.855 ton. Sementara itu sektor perkebunan dengan komoditas unggulannya kelapa telah berproduksi 34.126 ton dengan luas areal 35.668 ha. Demikian pula halnya dengan populasi ternak sapi yang mencapai 49.640 ekor dan ternak kerbau 2.877 ekor, serta ayam pedaging 13.970.292 ekor. Tingkat produksi daging sapi mencapai 744 ton, daging kerbau 98 ton dan daging ayam 7.371 ton (BPS Kabupaten Lampung Selatan, 2010b).

Dengan melihat besarnya potensi sektor pertanian sebagai penyumbang terbesar pendapatan masyarakat Lampung Selatan dan sebagian besar penyebaran penduduk berada di pedesaan, maka salah satu sasaran lokasi penyaluran dana bantuan pemerintah melalui Kementerian Pertanian yang dikenal dengan nama Program Pengembangan Usaha Agribisnis Perdesaan (PUAP) tahun 2008 dan 2009 dialokasikan untuk Kabupaten Lampung Selatan.

Program PUAP merupakan program terobosan Menteri Pertanian yang bertujuan untuk mengurangi kemiskinan dan pengangguran melalui penumbuhan dan pengembangan usaha agribisnis di perdesaan sesuai potensi wilayah; meningkatkan kemampuan pelaku usaha agribisnis, pengurus Gabungan Kelompok Tani (Gapoktan), penyuluh dan penyelia mitra tani; memberdayakan kelembagaan petani dan ekonomi pedesaan untuk pengembangan kegiatan usaha agribisnis, serta meningkatkan fungsi kelembagaan ekonomi petani menjadi jejaring atau mitra lembaga keuangan dalam rangka akses ke permodalan (Pusat Pembiayaan, 2009).

Secara umum, usaha di sektor pertanian masih dianggap beresiko tinggi, sedangkan skim kredit masih terbatas untuk usaha produksi, belum menyentuh kegiatan pra dan pasca produksi dan sampai saat ini belum berkembangnya lembaga penjamin serta belum adanya lembaga keuangan khusus yang menangani sektor pertanian (Syahyuti, 2008).

Implikasi dari berbagai permasalahan tersebut, melalui Program PUAP, penyaluran bantuan permodalan dilaksanakan oleh Pusat
Pembiayaan Kementerian Pertanian. Sejak tahun 2008 dana tersebut disalurkan di 32 provinsi kepada sebanyak 11.321 gapoktan atau senilai Rp3.502.229.242.000 pada tahun 2008 dan senilai Rp351.904.730.000 pada tahun 2009. Penyaluran bantuan permodalan (PUAP) di Provinsi Lampung seluruhnya pada 9 kabupaten/ kota kepada 417 Gapoktan pada tahun 2008 senilai Rp27.234.301.000 dan pada tahun 2009 senilai Rp12.997.197.000. Khusus untuk Kabupaten Lampung Selatan bantuan permodalan seluruhnya disalurkan kepada 74 Gapoktan dengan perincian pada tahun 2008 kepada 35 Gapoktan senilai Rp3.492.040.000 dan pada tahun 2009 disalurkan kepada 39 Gapoktan senilai Rp3.898.324.000 (Pusat Pembiayaan, 2010a).

Dalam pelaksanaan di lapangan masih terdapat berbagai permasalahan yang ditemukan, antara lain penyaluran dan pemanfaatan dana PUAP tidak tepat sasaran kepada anggota kelompok/kelompok tani yang membutuhkan dan penggunaan dana bantuan tidak sesuai dengan Rencana Usaha Anggota (RUA)/Rencana Usaha Kelompok (RUK)/Rencana Usaha Bersama (RUB). Selain itu juga penyuluh pendamping dan Penyelia Mitra Tani (PMT) belum melaksanakan tugas dan tanggungjawabnya sesuai dengan Pedoman Teknis PUAP, kelembagaan keuangan mikro tidak terbentuk serta tidak terjadi peningkatan modal kelompok.

Berdasarkan latar belakang kajian dan rumusan masalah yang telah diuraikan, maka tujuan dari kajian ini adalah untuk menganalisis efektivitas kinerja usaha kecil setelah adanya penyaluran bantuan permodalan melalui Program PUAP.

\section{METODOLOGI}

Kajian dilakukan di Kabupaten Lampung Selatan, Provinsi Lampung. Hal ini disebabkan selain provinsi tersebut adalah target sasaran wilayah program PUAP, juga karena sebagian besar penduduknya memiliki mata pencaharian pada sektor pertanian. Waktu kajian dilaksanakan selama tiga bulan, dari bulan Mei sampai dengan Juli 2011

Jenis data yang diperlukan dalam penelitian ini adalah data primer dan sekunder. Sumber data primer berasal dari responden yang diperoleh dengan menggunakan teknik pengumpulan data melalui penyebaran kuesioner. Responden dalam penelitian ini adalah anggota kelompok tani, baik petani pemilik, petani penggarap, buruh tani, maupun rumah tangga tani. Populasi target pada kajian ini adalah sebanyak 617 kelompok tani pada 74 Gapoktan di Kabupaten Lampung Selatan Provinsi Lampung sasaran program PUAP.

Metode pemilihan contoh yang digunakan adalah penarikan contoh tanpa peluang (nonprobability sampling). Pemilihan metode ini umumnya berdasarkan pada pertimbangan waktu relatif cepat dan biaya relatif lebih murah. Lebih 
spesifik lagi, dalam penelitian ini digunakan pemilihan contoh purposif (purposive sampling). Penentuan banyaknya contoh minimun yang diambil dari populasi penelitian menggunakan rumus Slovin (Umar, 2008) sebagai berikut:

$n \geq \frac{N}{1+N \cdot e^{2}}$

Keterangan:

$\mathrm{n}=$ ukuran contoh

$\mathrm{N}=$ ukuran populasi relatif banyak

e $=$ kelonggaran ketidaktelitian karena

kesalahan pengambilan contoh yang dapat ditoleransi

Berkaitan dengan penentuan banyaknya contoh yang diambil dari populasi, yaitu apabila subyek kurang dari 100, maka diambil semua. Apabila subyek lebih dari 100 maka kelonggaran ketelitian dapat diambil 10\%-15\% (Riduwan \& Kuncoro, 2008).

Kelonggaran ketidaktelitian menunjukkan tingkat ketepatan hasil penelitian berdasarkan contoh dan menggambarkan karakteristik populasi. Kelonggaran ketidaktelitian yang digunakan $10 \%$, sehingga ukuran contoh dihitung berikut:

$$
\begin{aligned}
& \mathrm{n} \geq \frac{617}{(1+617) x(0,10)^{2}} \\
& \mathrm{n} \geq 86,052 ; \text { dibuatkan } 86
\end{aligned}
$$

Dengan demikian ukuran contoh minimal dalam penelitian ini sebanyak 86 contoh kelompok tani yang tergabung dalam Gapoktan penerima PUAP.

Analisis data yang digunakan adalah analisis deskriptif dengan metode pengujian berikut:

\section{Uji Kesahihan (Test of Validity)}

Uji kesahihan dengan menggunakan rumus teknik korelasi "product moment pearson", yaitu:

$$
r=\frac{n\left(\sum X Y\right)-\left(\sum X \sum Y\right)}{\sqrt{\left[n \sum X^{2}-\left(\sum X\right)^{2}\right]\left[n \sum Y^{2}-\left(\sum Y\right)^{2}\right]}}
$$

Keterangan:

$X=$ Skor pernyataan tertentu dari masingmasing kuesioner

$\mathrm{X}_{1}=$ Kesesuaian Perencanaan dengan Pelaksanaan Kegiatan Usahatani

$\mathrm{X}_{2}=$ Pengembangan Agribisnis Perdesaan

$\mathrm{X}_{3}=$ Pengembangan Keuangan Mikro

$\mathrm{X}_{4}=$ Penilaian terhadap Pendampingan

$\mathrm{Y}=$ Skor total semua pernyataan dari masingmasing kuesioner (Kinerja Usaha Kecil Pertanian)

$\mathrm{n}=$ Jumlah responden

$r=$ Koefisien korelasi (derajat hubungan antara $r_{\text {hitung }}$ dan $\mathrm{X}_{\text {tabel }}=0,3$ )

Jika dari hasil analisis tersebut diperoleh nilai koefisien korelasi lebih dari atau sama dengan 0,3 ( $r_{\text {hitung }} \geq 0,3$ ), maka data tersebut adalah valid, berarti layak untuk digunakan dalam pengujian hipotesis. Bila nilai koefisien korelasinya kurang dari 0,3 ( $r_{\text {hitung }}<0,3$ ) menunjukkan bahwa data tersebut tidak valid berarti tidak layak untuk digunakan dalam pengujian hipotesis dan disisihkan dari analisis selanjutnya. Setelah yang digunakan dalam penelitian ini valid, maka dilanjutkan dengan uji keandalan (Kaplan \& Saccuzzo, 1993).

\section{Uji Keandalan (Test Of Reliability)}

Uji ini menggunakan rumus Cronbach's Alpha, yaitu:

$$
r_{11}=\left(\frac{k}{k-1}\right)\left(1-\frac{\sum \sigma b^{2}}{\sigma t^{2}}\right)
$$

$$
\begin{array}{ll}
\mathrm{r}_{11} & =\text { nilai reliabilitas } \\
\mathrm{k} & =\text { banyak butir pertanyaan } \\
\sigma \mathrm{t}^{2} & =\text { varian total } \\
\sum \sigma \mathrm{b}^{2} & =\text { jumlah varian butir }
\end{array}
$$

Setelah nilai koefisien reliabilitas $\left(r_{11}\right)$ diperoleh, maka ditetapkan nilai koefisien reliabilitas paling kecil yang dianggap reliabel. Koefisien reliabilitas 0,70-0,80 dinilai cukup baik untuk tujuan penelitian dasar (Kaplan \& Saccuzzo, 1993).

Analisis data yang digunakan adalah analisis regresi berganda (multiple regression analysis), yang didasari hubungan fungsional atau hubungan sebab akibat peubah bebas $\left(X_{1}, X_{2}\right.$, $\mathrm{X}_{3}$,dan $\mathrm{X}_{4}$ ) terhadap peubah terikat $(\mathrm{Y})$, atau dengan alasan bahwa analisis ini dapat digunakan sebagai model prediksi atau mencari pengaruh terhadap satu peubah terikat dengan beberapa peubah bebas (Riduwan \& Kuncoro, 2008) dengan model analisis berikut:

Keterangan:

$$
Y=\beta_{0}+\beta_{1} X_{1}+\beta_{2} X_{2}+\beta_{3} X_{3}+\beta_{4} X_{4}+\varepsilon
$$

$\mathrm{Y}=$ Kinerja Usaha Kecil Pertanian

$\mathrm{X}_{1}=$ Kesesuaian Perencanaan dengan

Pelaksanaan Kegiatan Usahatani

$\mathrm{X}_{2}=$ Pengembangan Agribisnis Perdesaan

$\mathrm{X}_{3}=$ Pengembangan Keuangan Mikro

$\mathrm{X}_{4}=$ Penilaian terhadap Pendampingan

$\beta_{0}=$ Konstanta

$\beta_{1}=$ Koefisien Regresi Variabel $X_{1}$

$\beta_{2}=$ Koefisien Regresi Variabel $X_{2}$

$\beta_{3}=$ Koefisien Regresi Variabel $X_{3}$

$\beta_{4}=$ Koefisien Regresi Variabel $X_{4}$

$\varepsilon=$ error term

Model regresi linear berganda disebut model yang baik, jika model tersebut memenuhi asumsi normalitas data dan terbebas dari asumsiasumsi klasik statistik, yaitu multi-kolinieritas, heteroskedastisitas dan autokorelasi. Proses pengujian asumsi klasik statistik dilakukan simultan dengan proses uji regresi, sehingga langkah-langkah yang dilakukan dalam pengujian tersebut menggunakan Statistical Package for Social Science (SPSS) for Windows version 13. 


\section{Pengujian Hipotesis}

Pengujian hipotesis dimaksudkan untuk melihat tingkat nyata, yaitu hipotesis penelitian yang telah diuji dengan data contoh dapat diberlakukan, atau tidak untuk populasi dan untuk menentukan apakah jawaban teoritis yang terkandung dalam pernyataan hipotesis didukung fakta yang dikumpulkan dan dianalisis dalam proses pengujian data (Indriantoro \& Supomo, 2002).

\section{Hipotesis}

Pengujian hipotesis untuk korelasi ini dirumuskan dengan hipotesis nol $\left(\mathrm{H}_{\mathrm{o}}\right)$ dan hipotesis pengganti $\left(\mathrm{H}_{\mathrm{a}}\right)$ berikut:

$Y=$ Kinerja Usaha Kecil Pertanian

$\mathrm{X}_{1}=$ Kesesuaian Perencanaan dengan

Pelaksanaan Kegiatan Usahatani

$\mathrm{X}_{2}=$ Pengembangan Agribisnis Perdesaan

$\mathrm{X}_{3}=$ Pengembangan Keuangan Mikro

$\mathrm{X}_{4}=$ Penilaian terhadap Pendampingan

a. Kesesuaian Perencanaan dengan Pelaksanaan Kegiatan Usahatani, Pengembangan Agribisnis Perdesaan, Pengembangan Keuangan Mikro, dan Penilaian terhadap Pendampingan, secara simultan berpengaruh nyata terhadap Kinerja Usaha Kecil Pertanian.

- Ho: $\beta_{1}, \beta_{2}, \beta_{3}, \beta_{4} \leq 0$; menunjukkan bahwa $\left(X_{1}\right),\left(X_{2}\right),\left(X_{3}\right)$ dan $\left(X_{4}\right)$, secara simultan tidak berpengaruh secara nyata terhadap (Y).

- Ha: $\beta_{1}, \beta_{2}, \beta_{3}, \beta_{4}>0$; menunjukkan bahwa $\left(X_{1}\right),\left(X_{2}\right),\left(X_{3}\right)$ dan $\left(X_{4}\right)$, secara simultan terdapat pengaruh nyata terhadap $(Y)$.

b. Kesesuaian Perencanaan dengan Pelaksanaan Kegiatan Usahatani, Pengembangan Agribisnis Perdesaan, Pengembangan Keuangan Mikro, dan Penilaian terhadap Pendampingan, secara parsial berpengaruh nyata terhadap Kinerja Usaha Kecil Pertanian.

- $\mathrm{Ho}_{1}: \beta_{1}, \beta_{2}, \beta_{3}, \beta_{4} \leq 0$; menunjukkan bahwa $\left(X_{1}\right),\left(X_{2}\right),\left(X_{3}\right)$ dan $\left(X_{4}\right)$, secara parsial tidak berpengaruh secara nyata terhadap $(Y)$.

- $\mathrm{Ha}_{1}: \beta_{1}, \beta_{2}, \beta_{3}, \beta_{4}>0$; menunjukkan bahwa $\left(X_{1}\right),\left(X_{2}\right),\left(X_{3}\right)$ dan $\left(X_{4}\right)$, secara parsial berpengaruh secara nyata terhadap $(Y)$.

\section{Pengujian Secara Simultan}

Pengujian ini dilakukan untuk mengetahui nyatanya pengaruh peubah independen terhadap peubah dependen secara simultan, atau secara keseluruhan (uji hipotesis pertama). Untuk menghitung nilai $\mathrm{F}_{\text {hitung }}$ digunakan rumus:

$$
F_{\text {hitung }}=\frac{(n-k-1) R^{2}}{k\left(1-R^{2}\right)}
$$

Keterangan:

$\mathrm{n}=$ jumlah contoh

$\mathrm{k}=$ jumlah peubah bebas

$\mathrm{R}^{2}=$ koefisien determinasi

Hasil perhitungan $F_{\text {hitung kemudian }}$ dibandingkan dengan nilai $F_{\text {tabel }}$ pada tingkat keyakinan $95 \%(\alpha=0,05)$ (Riduwan \& Kuncoro, 2008), dengan kriteria keputusan berikut:

Jika $\mathrm{F}_{\text {hitung }}>\mathrm{F}_{\text {tabel, }}$, maka $\mathrm{H}_{0}$ ditolak dan $\mathrm{H}_{\mathrm{a}}$ diterima (nyata)

Jika $F_{\text {hitung }} \leq \mathrm{F}_{\text {tabel, }}$, maka $\mathrm{H}_{0}$ diterima dan $\mathrm{H}_{\mathrm{a}}$ ditolak (tidak nyata)

\section{Pengujian Secara Parsial}

Pengujian ini dilakukan untuk mengetahui nyatanya pengaruh masing-masing peubah independen secara parsial terhadap peubah dependen (Riduwan \& Kuncoro, 2008) dan untuk menghitung nilai $t_{\text {hitung }}$ digunakan rumus berikut:

$$
t_{\text {hitung }}=\frac{\beta_{i}}{S \beta_{i}}
$$

Keterangan:

$\beta_{\mathrm{i}} \quad=$ koefisien regresi peubah independen ke-i

$S \beta_{i}=$ galat dari peubah independen ke-i

Dari perhitungan tersebut, selanjutnya membandingkan antara nilai $t_{\text {hitung }}$ dengan nilai $t_{\text {tabel }}$ pada tingkat kepercayaan $95 \%(\alpha=0,05)$, dengan kriteria berikut:

- Jika $-\mathrm{t}_{\text {tabel }} \leq \mathrm{t}_{\text {hitung }} \leq \mathrm{t}_{\text {tabel }}$, maka $\mathrm{H}_{0}$ diterima dan $\mathrm{H}_{\mathrm{a}}$ ditolak

- Jika $t_{\text {hitung }}<-t_{\text {tabel }}$ atau $t_{\text {hitung }}>t_{\text {tabel }}$, maka $\mathrm{H}_{0}$ ditolak dan $\mathrm{H}_{\mathrm{a}}$ diterima

\section{Pengujian Koefisien Determinasi $\left(\mathbf{R}^{\mathbf{2}}\right)$}

Koefisien determinasi digunakan untuk mengetahui seberapa besar peubah $X$ mempunyai kontribusi, atau ikut menentukan peubah $\mathrm{Y}$, biasanya dinyatakan dalam presentase (Riduwan \& Kuncoro, 2008). Rumus analisis koefisien determinasi berikut:

Keterangan:

$$
K D=R^{2} \times 100 \%
$$

$\mathrm{KD}=$ nilai koefisien determinasi

$\mathrm{R}^{2}=$ nilai koefisien korelasi

Nilai $R^{2}$ berada antara 0 dan 1 . Semakin mendekati nilai $1(100 \%)$, maka semakin besar pengaruh peubah bebas terhadap peubah terikat.

\section{HASIL DAN PEMBAHASAN}

Berdasarkan tahun penyaluran bantuan PUAP, yaitu pada tahun 2008 dan 2009, sebanyak $55,81 \%$ adalah penerima bantuan PUAP tahun 2009 dan 44,19\% adalah penerima bantuan PUAP tahun 2008. Pengambilan jumlah contoh untuk masing-masing tahun penyaluran dilakukan secara proporsional berdasarkan jumlah gapoktan penerima bantuan pada tahun 2009 yang lebih banyak, jika dibandingkan dengan Gapoktan penerima bantuan tahun 2008.

Berdasarkan sebaran jenis kelamin, $79,07 \%$ adalah pria dan $20,93 \%$ adalah wanita. Berdasarkan latar belakang dan tingkat pendidikan, diperoleh sarjana (S1) 9,30\%, Diploma III $11,63 \%$, pendidikan Sekolah Menengah Atas 
(SMA) 37,12\%, Sekolah Menengah Pertama (SMP) $29,07 \%$ dan tamatan Sekolah Dasar (SD) $12,79 \%$. Berdasarkan umur, diperoleh 3,49\% berumur 20-25 tahun, $8,14 \%$ berumur $26-30$ tahun, $30,23 \%$ berumur $31-35$ tahun, $25,58 \%$ berumur 36-40 tahun, $17,44 \%$ berumur $41-45$ tahun dan $15,12 \%$ berumur di atas 46 tahun.

\section{Analisis deskriptif}

Gambaran deskriptif data penelitian memberikan pemahaman bagaimana deskripsi secara lebih rinci terhadap sebuah peubah, dimana dalam kajian ini peubah Kesesuaian Perencanaan dengan Pelaksanaan Kegiatan Usaha Tani $\left(X_{1}\right)$, peubah Pengembangan Agribisnis Perdesaan $\left(\mathrm{X}_{2}\right)$, peubah Pengembangan Keuangan Mikro $\left(X_{3}\right)$, peubah Penilaian terhadap Pendampingan $\left(\mathrm{X}_{4}\right)$ dan peubah Kinerja Usaha Kecil Pertanian $(\mathrm{Y})$.

\section{Kesesuaian Perencanaan dengan Pelaksanaan Kegiatan Usaha Tani $\left(X_{1}\right)$}

Hasil analisis menunjukkan $67,4 \%$ menyatakan sangat penting dan $32,6 \%$ menyatakan penting terhadap adanya bantuan modal usaha untuk usaha pertanian. Sebagian besar kelompok $(83,7 \%)$ mengetahui tujuan dari pemberian bantuan PUAP, meskipun masih ada 16,3\% kelompok yang tidak mengetahuinya.

Tanggapan kelompok mengenai RUB dan RUK, yaitu $88,4 \%$ setuju, dan ragu-ragu $11,6 \%$. Sebanyak $64 \%$ setuju bahwa dalam penyusunan RUA, RUK dan RUB, sebaiknya disesuaikan dengan potensi dan sumber daya yang dimiliki, di lain pihak terdapat $30,2 \%$ yang masih ragu-ragu dan hanya sebagian kecil $(5,8 \%)$ tidak setuju.

Penyusunan RUA, RUK dan RUB, yang disesuaikan dengan bidang usaha budi daya pertanian dan non budi daya pertanian yang berbasis pertanian sebanyak $72,1 \%$ menyatakan setuju dan sisanya $22,1 \%$ ragu-ragu, serta tidak setuju $5,8 \%$.

Pada tingkat kesesuaian penggunaan bantuan dengan RUA, RUK dan RUB, 97,7\% menyetujui pemanfaatan realisasi bantuan modal yang telah sesuai dengan perencanaan. Setiap transaksi yang dilakukan terhadap pemanfaatan dana bantuan PUAP, telah dicatat dan didokumentasikan dengan baik. Hal ini telah dilakukan dengan tertib oleh $64 \%$ responden, namun masih terdapat $22,1 \%$ yang masih belum sepenuhnya tertib, dan sebanyak $13,9 \%$ tidak tertib melakukan pencatatan.

Pada umumnya $(80,3 \%)$ menyatakan sangat penting memerlukan kelengkapan administrasi kelompok yang dibuat dengan teratur dan rapi, sedangkan yang menyatakan tidak penting $11,6 \%$ dan sisanya $(8,1 \%)$ ragu-ragu.

Sebanyak $54,6 \%$ menyatakan penting untuk melakukan konsultasi dan koordinasi secara reguler mengenai perkembangan kegiatan usaha pertanian kepada Pemerintah, penyuluh dan PMT, sisanya $(31,4 \%)$ menyatakan ragu-ragu dan $14 \%$ menyatakan tidak penting. Pada aspek ketertiban pelaporan tanggapan kelompok yang menyatakan penting untuk melaporkan secara berkala mengenai perkembangan PUAP 64\%, tidak penting $23,2 \%$ dan $12,8 \%$ ragu-ragu.

\section{Pengujian Data}

\section{Uji Kesahihan}

Hasil perhitungan uji validitas ditentukan dengan kriteria yang digunakan adalah item valid, berarti layak untuk digunakan dalam pengujian hipotesis apabila diperoleh $r_{\text {hitung }} \geq 0,3$, maka data tersebut adalah valid, sedangkan jika $r_{\text {hitung }}<0,3$ berarti data tersebut tidak valid, berarti tidak layak untuk digunakan dalam pengujian hipotesis (Kapplan dan Saccuzzo, 1993).

Peubah Kesesuaian Perencanaan dengan Pelaksanaan kegiatan Usaha Tani diukur dengan 10 item pernyataan sebagai indikator. Berdasarkan pada hasil uji validitas terhadap 10 item pernyataan yang digunakan diperoleh kesepuluh item pernyataan memiliki nilai $r_{\text {hitung }} \geq 0,3$ sehingga keseluruhan pernyataan menunjukkan valid dan dapat digunakan untuk analisis selanjutnya (Tabel 1). Hal yang sama juga diperoleh untuk peubah pengembangan agribisnis pedesaan (Tabel 2), peubah pengembangan keuangan mikrl (Tabel 3), peubah penilaian terhadap pendampingan (Tabel 4), dan peubah kinerja usaha tani (Tabel 5).

Tabel 1. Hasil uji validitas peubah $\mathrm{X}_{1}$

\begin{tabular}{cccc}
\hline Pernyataan & $\begin{array}{c}\text { Koefisien } \\
\text { Korelasi }\end{array}$ & $\begin{array}{c}\text { Nilai } \\
\text { Batas } r\end{array}$ & $\begin{array}{c}\text { Kesim- } \\
\text { pulan }\end{array}$ \\
\hline P1 & 0,770 & 0,3 & valid \\
P2 & 0,817 & & \\
P3 & 0,416 & & \\
P4 & 0,799 & & \\
P5 & 0,714 & & \\
P6 & 0,415 & & \\
P7 & 0,651 & & \\
P8 & 0,813 & & \\
P9 & 0,624 & & \\
\hline P10 & 0,822 & 0,3 & valid \\
\hline
\end{tabular}

Tabel 2. Hasil uji validitas peubah $\mathrm{X}_{2}$

\begin{tabular}{cccc}
\hline Pernyataan & $\begin{array}{c}\text { Koefisien } \\
\text { Korelasi }\end{array}$ & $\begin{array}{c}\text { Nilai } \\
\text { Batas } r\end{array}$ & $\begin{array}{c}\text { Kesim- } \\
\text { pulan }\end{array}$ \\
\hline P11 & 0,807 & 0,3 & valid \\
P12 & 0,739 & & \\
P13 & 0,868 & & \\
P14 & 0,397 & & \\
P15 & 0,833 & & \\
P16 & 0,464 & & \\
P17 & 0,472 & & \\
P18 & 0,746 & & \\
P19 & 0,612 & & \\
P20 & 0,770 & & \\
\hline
\end{tabular}


Tabel 3. Hasil uji validitas peubah $X_{3}$

\begin{tabular}{cccc}
\hline Pernyataan & $\begin{array}{c}\text { Koefisien } \\
\text { Korelasi }\end{array}$ & $\begin{array}{c}\text { Nilai } \\
\text { Batas } r\end{array}$ & $\begin{array}{c}\text { Kesim- } \\
\text { pulan }\end{array}$ \\
\hline P21 & 0,523 & 0,3 & valid \\
P22 & 0,770 & & \\
P23 & 0,528 & & \\
P24 & 0,779 & & \\
P25 & 0,661 & & \\
P26 & 0,631 & & \\
P27 & 0,893 & & \\
P28 & 0,680 & & \\
P29 & 0,752 & & \\
P30 & 0,718 & & \\
\hline
\end{tabular}

Tabel 4. Hasil uji validitas peubah $\mathrm{X}_{4}$

\begin{tabular}{cccc}
\hline Pernyataan & $\begin{array}{c}\text { Koefisien } \\
\text { Korelasi }\end{array}$ & $\begin{array}{c}\text { Nilai } \\
\text { Batas r }\end{array}$ & $\begin{array}{c}\text { Kesim- } \\
\text { pulan }\end{array}$ \\
\hline P31 & 0,767 & 0,3 & valid \\
P32 & 0,597 & & \\
P33 & 0,473 & & \\
P34 & 0,856 & & \\
P35 & 0,725 & & \\
P36 & 0,910 & & \\
P37 & 0,705 & & \\
P38 & 0,553 & & \\
P39 & 0,904 & & \\
P40 & 0,828 & & \\
\hline
\end{tabular}

Tabel 5. Hasil uji validitas peubah $Y$

\begin{tabular}{cccc}
\hline Pernyataan & $\begin{array}{c}\text { Koefisien } \\
\text { Korelasi }\end{array}$ & $\begin{array}{c}\text { Nilai } \\
\text { Batas } r\end{array}$ & $\begin{array}{c}\text { Kesim- } \\
\text { pulan }\end{array}$ \\
\hline P41 & 0,777 & 0,3 & valid \\
P42 & 0,393 & & \\
P43 & 0,449 & & \\
P44 & 0,666 & & \\
P45 & 0,710 & & \\
P46 & 0,769 & & \\
P47 & 0,371 & & \\
P48 & 0,534 & & \\
P49 & 0,682 & & \\
P50 & 0,878 & & \\
\hline
\end{tabular}

\section{Uji Keandalan}

Pengujian reabilitas, atau uji keandalan dalam kajian ini diperoleh koefisien reliabilitas di atas 0,70 maka nilai tersebut cukup baik untuk tujuan penelitian/kajian dasar (Kapplan dan Saccuzzo, 1993). Hasil dari uji reliabilitas untuk masing-masing variabel $X$ dan $Y$ dalam penelitian ini dimuat pada Tabel 6 .

\section{Transformasi Data}

Mentransformasi data ordinal menjadi data interval bertujuan untuk memenuhi sebagian dari syarat analisis parametrik, yang mana data setidaknya berskala interval (Riduan dan Kuncoro. 2008). Dalam kajian ini kuesioner yang dibagikan adalah skala pengukuran ordinal, sehingga data yang diperoleh dari penyebaran kuesioner tersebut harus ditransformasikan untuk menaikkan tingkat pengukuran dari skala ordinal ke skala interval dengan menggunakan metode interval berurutan (methode of successive intervals). Dengan demikian semua data yang telah dinaikkan dari skala ordinal ke interval dapat digunakan sebagai input untuk analisis regresi.

Tabel 6. Hasil uji reliabilitas

\begin{tabular}{cccc}
\hline Peubah & $\begin{array}{c}\text { Koefisien } \\
\text { Reliabilitas }\end{array}$ & $\begin{array}{c}\text { Nilai } \\
\text { Batas }\end{array}$ & $\begin{array}{c}\text { Kesim- } \\
\text { pulan }\end{array}$ \\
\hline $\mathrm{X}_{1}$ & 0,869 & 0,7 & reliabel \\
$\mathrm{X}_{2}$ & 0,867 & & \\
$\mathrm{X}_{3}$ & 0,857 & & \\
$\mathrm{X}_{4}$ & 0,894 & & \\
$\mathrm{Y}$ & 0,813 & & \\
\hline
\end{tabular}

\section{Hasil Analisis Data}

Perhitungan koefisien regresi pada penelitian ini menggunakan software SPSS for Windows version 13 dan hasil perhitungan dimuat pada Tabel 7. Dari hasil pengolahan data (Tabel 7), diperoleh persamaan:

$$
Y=2,796+0,316 X_{1}+0,211 X_{2}+0,295 X_{3}+0,204 X_{4}
$$

Dari persamaan tersebut diperoleh nilai konstanta 2,796. Hal ini berarti, jika peubah kinerja usahatani $(Y)$ tidak dipengaruhi oleh keempat peubah bebasnya (kesesuaian perencanaan dengan kegiatan usahatani, pengem bangan agribisnis pedesaan, pengembangan keuangan mikro dan penilaian terhadap pendampingan bernilai nol, maka besarnya kinerja usaha tani akan bernilai 2,796.

Tanda koefisien regresi peubah bebas menunjukkan arah hubungan dari peubah yang bersangkutan dengan kinerja usahatani. Koefisien regresi untuk variabel bebas $X_{1}$ bernilai positif. Hal ini menunjukkan adanya hubungan searah antara peubah $\mathrm{X}_{1}$ dan peubah $\mathrm{Y}$. Koefisien regresi peubah $X_{1} \quad 0,316$, berarti untuk setiap pertambahan kesesuaian perencanaan dengan kegiatan usahatani $\left(X_{1}\right)$ sebesar satu satuan akan menyebabkan meningkatnya kinerja usahatani $(Y) 0,316$.

Koefisien regresi untuk peubah bebas $X_{2}$, $\mathrm{X}_{3}$ dan $\mathrm{X}_{4}$ bernilai positif. Hal ini menunjukkan adanya hubungan yang searah antara peubah $X_{2}$, $\mathrm{X}_{3}$, dan $\mathrm{X}_{4}$ dengan kinerja usaha tani $(\mathrm{Y})$. Koefisien regresi peubah $X_{2}$ 0,211, berarti untuk setiap pertambahan pengembangan agribisnis pedesaan $\left(\mathrm{X}_{2}\right)$ sebesar satu satuan akan menyebabkan meningkatnya Kinerja Usahatani (Y) 0,211. Koefisien regresi peubah $X_{3}$ 0,295 mengandung arti untuk setiap pertambahan pengembangan keuangan mikro $\left(X_{3}\right)$ sebesar satu satuan akan menyebabkan meningkatnya $(Y) 0,295$. Koefisien regresi peubah $X_{4}$ 0,204, mengandung arti untuk setiap pertambahan penilaian terhadap pendampingan $\left(\mathrm{X}_{4}\right)$ sebesar satu satuan akan menyebabkan meningkatnya Kinerja Usahatani $(Y)$ 0,204. 
Tabel 7. Hasil perhitungan koefisien regresi

\begin{tabular}{|c|c|c|c|c|c|c|}
\hline & \multirow[t]{2}{*}{ Model } & $\begin{array}{l}\text { Unstandardized } \\
\text { Coefficients }\end{array}$ & & $\begin{array}{c}\text { Standardized } \\
\text { Coefficients }\end{array}$ & \multirow[t]{2}{*}{$t$} & \multirow[t]{2}{*}{ Sig. } \\
\hline & & B & Std. Error & Beta & & \\
\hline \multirow[t]{5}{*}{1} & (Constant) & 2.796 & 2.385 & & 1.172 & .245 \\
\hline & $\left(\mathrm{X}_{1}\right)$ & .316 & .074 & .343 & 4.278 & .000 \\
\hline & $\left(X_{2}\right)$ & .211 & .065 & .245 & 3.245 & .002 \\
\hline & $\left(X_{3}\right)$ & .295 & .072 & .290 & 4.081 & .000 \\
\hline & $\left(X_{4}\right)$ & .204 & .076 & .232 & 2.687 & .009 \\
\hline
\end{tabular}

a. Dependent Variable: Kinerja Usahatani (Y)

\section{Pengujian Asumsi Klasik Regresi}

Analisis regresi linear berganda memerlukan uji persyaratan yang sangat ketat. Uji persyaratan pada regresi linear berganda biasa disebut dengan uji asumsi klasik. Persyaratan awal untuk menggunakan regresi adalah peubah penelitian harus diukur paling rendah dalam bentuk interval, atau rasio. Persyaratan lainnya berupa uji normalitas, uji multikolinearitas, uji heterokedastisitas, dan uji autokorelasi.

\section{Uji Normalitas}

Uji normalitas dilakukan untuk mengetahui apakah data yang diambil berasal dari populasi berdistribusi normal. Model regresi yang baik adalah berdistribusi normal, atau mendekati normal. Jika data tidak mengikuti pola sebaran distribusi normal, maka akan diperoleh taksiran bias. Pengujian normalitas dilakukan melalui tes Kolmogorov-Smirnov koreksi Lilliefors (Tabel 8).

Tabel 8. Uji Normalitas

\begin{tabular}{|c|c|c|}
\hline & & $\begin{array}{c}\text { Unstandardized } \\
\text { Residual }\end{array}$ \\
\hline $\mathrm{N}$ & & 86 \\
\hline Normal Parameters ${ }^{\text {a.b }}$ & Mean & .00000000 \\
\hline & Std. Deviation & 2.81228010 \\
\hline Most Extreme & Absolute & .071 \\
\hline Differences & $\begin{array}{l}\text { Positive } \\
\text { Negative }\end{array}$ & $\begin{array}{l}.046 \\
071\end{array}$ \\
\hline Kolmogorov-Smirnov Z & & .654 \\
\hline Asymp. Sig. (2-tailed) & & .785 \\
\hline
\end{tabular}

Analisis kenormalan berdasarkan metode Kolmogorov-Smirnov mensyaratkan kurva normal apabila nilai Asymp. Sig. > 0,05. Dalam analisis regresi yang diuji kenormalannya maximum error adalah residual, atau peubah gangguan yang bersifat stokastik acak, sehingga data di atas dapat digunakan, karena peubah residu berdistribusi normal.

\section{Uji Multikolinearitas}

Multikolinieritas merupakan sesuatu dimana beberapa atau semua peubah bebas berkorelasi tinggi. Untuk mendeteksi ada tidaknya multikolinearitas digunakan Variance Inflation Factors (VIF). Dari Tabel 9 dapat dilihat bahwa nilai VIF $<10$, sehingga dapat disimpulkan bahwa tidak terdapat multikolinearitas dalam data.
Tabel 9. Uji Multikolinearitas

\begin{tabular}{rrrr}
\hline & \multirow{2}{*}{ Model } & \multicolumn{2}{c}{ Collinearity statistics } \\
\cline { 3 - 4 } & & Tolerance & VIF \\
\hline 1 & $\left(\mathrm{X}_{1}\right)$ & .677 & 1.478 \\
& $\left(\mathrm{X}_{2}\right)$ & .765 & 1.307 \\
& $\left(\mathrm{X}_{3}\right)$ & .861 & 1.161 \\
& $\left(\mathrm{X}_{4}\right)$ & .582 & 1.717 \\
\hline
\end{tabular}

a. Dependent Variable: Kinerja Usahatani (Y)

\section{Uji Autokorelasi}

Uji autokorelasi dilakukan dengan menggunakan uji statistik Durbin Watson, yaitu dengan membandingkan angka Durbin-Watson hitung (DW) dengan nilai kritisnya (dL dan dU). Kriteria pengambilan kesimpulan:

1. Jika $\mathrm{DW}<\mathrm{dL}$ atau $\mathrm{DW}>4-\mathrm{dL}$, maka terdapat autokorelasi.

2. Jika $\mathrm{dL}<\mathrm{DW}<4-\mathrm{dU}$, maka tidak terdapat autokorelasi.

3. Jika dL $\leq \mathrm{DW} \leq \mathrm{dU}$ atau $4-\mathrm{dU} \leq \mathrm{DW} \leq 4-\mathrm{dL}$, uji Durbin Watson tidak menghasilkan kesimpulan yang pasti (inconclusive).

Dengan ukuran contoh $\mathrm{n}=86, \alpha=0,05$ dan banyaknya peubah bebas $\mathrm{k}=4$, didapatkan nilai kritis $\mathrm{dL}=1,728$ dan $\mathrm{dU}=1,810$. Nilai DurbinWatson 2,075 berada di antara dL $(1,728)<\mathrm{DW}$ $(2,075)<4-d U(2,190)$, maka dapat disimpulkan data tersebut tidak terjadi pelanggaran asumsi autokorelasi.

\section{Uji Heteroskedastisitas}

Uji heteroskedastisitas bertujuan menguji, apakah dalam model regresi terjadi ketidaksamaan ragam dari residual satu pengamatan ke pengamatan yang lain. Jika ragam dari residual satu pengamatan ke pengamatan lain tetap, maka disebut homoskedastisitas. Untuk menguji ada tidaknya heteroskedastisitas dilakukan dengan cara mengkorelasikan setiap peubah bebas dengan nilai mutlak residualnya menggunakan korelasi Rank Spearman (Tabel 10).

Dari output di atas dapat dilihat bahwa tidak terdapat korelasi nyata. Hal ini dilihat dari nilai $\mathrm{p}$ value $(\mathrm{Sig})>0,05$, sehingga dapat disimpulkan tidak terjadi heteroskedastisitas pada model regresi.

Berdasarkan seluruh hasil pengujian (Tabel 10), tidak diperoleh pelanggaran terhadap asumsi regresi klasik, maka analisis regresi selanjutnya dapat dilakukan. 
Tabel 10. Uji Heteroskedastisitas

\begin{tabular}{lllr}
\hline & & abs_res \\
\hline Spearman's rho & Kesesuaian Perencanaan & Correlation Coefficient & -.014 \\
& dengan Pelaksanaan Kegiatan & Sig. (2-tailed) & .901 \\
& Usaha Tani (X1) & $\mathrm{N}$ & 86 \\
Pengembangan Agribisnis & Correlation Coefficient & -.035 \\
Perdesaan (X2) & Sig. (2-tailed) & .752 \\
& $\mathrm{~N}$ & 86 \\
Pengembangan Keuangan & Correlation Coefficient & -.171 \\
Mikro (X3) & Sig. (2-tailed) & .117 \\
& $\mathrm{~N}$ & 86 \\
Penilaian Terhadap & Correlation Coefficient & .109 \\
Pendampingan (X4) & Sig. (2-tailed) & .318 \\
& $\mathrm{~N}$ & 86 \\
Kinerja Usaha Tani (Y) & Correlation Coefficient & -.031 \\
& Sig. (2-tailed) & .780 \\
& $\mathrm{~N}$ & 86 \\
\hline
\end{tabular}

\section{Pengujian Hipotesis}

Pengujian Hipotesis Secara Overall (Uji F)

Untuk mengetahui nyata atau tidaknya suatu pengaruh dari peubah-peubah bebas secara bersama-sama atas suatu peubah tidak bebas digunakan uji $\mathrm{F}$.

Ho : Tidak ada pengaruh nyata dari Kesesuaian Perencanaan dengan Pelaksanaan Kegiatan Usaha Tani, Pengembangan Agribisnis Perdesaan, Pengembangan Keuangan Mikro dan Penilaian terhadap Pendampingan secara simultan terhadap Kinerja Usaha Tani.

$\mathrm{Ha}$ : Ada pengaruh nyata dari Kesesuaian Perencanaan dengan Pelaksanaan Kegiatan Usaha Tani, Pengembangan Agribisnis Perdesaan, Pengembangan Keuangan Mikro dan Penilaian Terhadap Pendampingan secara simultan terhadap Kinerja Usaha Tani.

$\alpha=5 \%$

Statistik Uji:

$$
F=\frac{R^{2}(n-k-1)}{k\left(1-R^{2}\right)}
$$

Kriteria Uji : 1. Terima Ho jika $F$ hitung $<F$ tabel

2. Tolak Ho jika $F$ hitung $\geq F$ tabel

$\mathrm{F}$ tabel $=\mathrm{F}_{\alpha ;(\mathrm{df} 1, \mathrm{df} 2)} ; \mathrm{df} 1=\mathrm{k}, \mathrm{df} 2=\mathrm{n}-\mathrm{k}-1$

Hasil uji $F$ berdasarkan pengolahan SPSS disajikan pada Tabel 11.

Tabel 11. Hasil Uji F

\begin{tabular}{ccccc}
\hline F hitung & Df & $F$ table & Sig & Keterangan \\
\cline { 1 - 2 } 37,227 & df1 $=4$ & 2,48 & 0.000 & Ho ditolak \\
\cline { 2 - 2 } & df2 $=81$ & & & \\
\hline
\end{tabular}

Dari Tabel 11, diperoleh nilai $F$ hitung $(37,227)>F$ tabel $(2,48)$, maka Ho ditolak. Dengan demikian dapat disimpulkan bahwa secara simultan terdapat pengaruh nyata dari kesesuaian perencanaan dengan kegiatan usahatani, pengembangan agribisnis pedesaan, pengembangan keuangan mikro dan penilaian pendampingan terhadap efektifitas pemberian bantuan PUAP.

Dari Tabel 11 diperoleh nilai $F_{\text {hitung }} 37,227$ dengan taraf nyata $(p$-value $)=0,000$. Penentuan hasil pengujian (penerimaan, atau penolakan $\mathrm{H}_{\mathrm{o}}$ ) dapat dilakukan dengan membandingkan $F_{\text {hitung }}$ dengan $F_{\text {tabel }}$ atau juga dapat dilihat dari nilai nyatanya. Nilai $F_{\text {tabel }}$ untuk $\alpha=0,05$ dan derajat bebas $\mathrm{db}_{1}=\mathrm{k}=4$ dan $\mathrm{db}_{2}=\mathrm{n}-\mathrm{k}-1=81$ adalah 2,48 . Dengan demikian dapat disimpulkan bahwa pada tingkat nyata $5 \%$ ditemui kesesuaian perencanaan dengan pelaksanaan kegiatan usahatani, pengembangan agribisnis perdesaan, pengembangan keuangan mikro dan penilaian terhadap pendampingan secara simultan terdapat pengaruh nyata terhadap kinerja usaha tani.

\section{Pengujian Hipotesis Secara Parsial (Uji t)}

Untuk mengetahui nyata atau tidaknya suatu pengaruh dari peubah-peubah bebas secara parsial atas suatu peubah tidak bebas digunakan uji t.

Hipotesis:

1. $\mathrm{Ho}_{1}: \beta_{1}=0$ Kesesuaian perencanaan dengan kegiatan usahatani $\left(X_{1}\right)$ tidak berpengaruh nyata terhadap Kinerja Usaha Tani (Y).

$\mathrm{Ha}_{1}: \beta_{1} \neq 0$ Kesesuaian perencanaan dengan kegiatan usahatani $\left(X_{1}\right)$ berpengaruh nyata terhadap Kinerja Usaha Tani (Y).

2. $\mathrm{Ho}_{2}: \beta_{2}=0$ Pengembangan agribisnis pedeKesimpulan saan $\left(X_{2}\right)$ tidak berpengaruh nyata Adapengaruh terhadap Kinerja Usaha Tani $(Y)$.

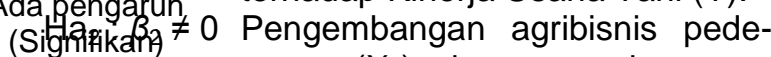
saan $\left(\mathrm{X}_{2}\right)$ berpengaruh nyata terhadap Kinerja Usaha Tani $(\mathrm{Y})$.

3. $\mathrm{Ho}_{3}: \beta_{3}=0$ Pengembangan keuangan mikro $\left(X_{3}\right)$ tidak berpengaruh nyata terhadap Kinerja Usaha Tani $(Y)$.

$\mathrm{Ha}_{3}: \beta_{3} \neq 0$ Pengembangan keuangan mikro $\left(\mathrm{X}_{3}\right)$ berpengaruh nyata terhadap Kinerja Usaha Tani $(Y)$. 
4. $\mathrm{Ho}_{4}: \beta_{4}=0$ Penilaian terhadap pendampingan $\left(\mathrm{X}_{4}\right)$ tidak berpengaruh nyata terhadap Kinerja Usaha Tani $(Y)$.

$\mathrm{Ha}_{4}: \beta_{4} \neq 0$ Penilaian terhadap pendampingan $\left(\mathrm{X}_{4}\right)$ berpengaruh nyata terhadap Kinerja Usaha Tani $(Y)$.

$\alpha=5 \%$

Statistik Uji:

$\mathrm{t}_{\text {hit }}=\frac{b}{S e(b)}$, derajat bebas $=\mathrm{n}-\mathrm{k}-1$

Kriteria Uji:

1. Terima Ho jika $-\mathrm{t}$ tabel $\leq \mathrm{t}$ hitung $\leq \mathrm{t}$ tabel

2. Tolak Ho jika t hitung $<-t$ tabel atau $t$ hitung $>t$ tabel

Hasil uji t berdasarkan pengolahan SPSS disajikan pada Tabel 12.

Berdasarkan Tabel 12 diperoleh hasil berikut:

1. Untuk peubah Kesesuaian Perencanaan dengan Kegiatan Usaha Tani $\left(\mathrm{X}_{1}\right)$ diperoleh nilai $t$ hitung $(4,278)>t$ tabel $(1,99)$, Ho ditolak, maka kesesuaian Perencanaan dengan Kegiatan Usaha Tani $\left(\mathrm{X}_{1}\right)$ secara parsial memiliki pengaruh nyata terhadap Kinerja Usaha Tani (Y).

2. Untuk peubah Pengembangan Agribisnis Perdesaan $\left(\mathrm{X}_{2}\right)$ diperoleh nilai t hitung $(3,245)$ $>\mathrm{t}$ tabel $(1,99)$, Ho ditolak, maka Pengembangan Agribisnis Perdesaan $\left(X_{2}\right)$ secara parsial memiliki pengaruh nyata terhadap Kinerja Usaha Tani (Y).

3. Untuk peubah Pengembangan Keuangan Mikro $\left(X_{3}\right)$ diperoleh nilai $t$ hitung $(4,081)>t$ tabel $(1,99)$, Ho ditolak, maka Pengembangan Keuangan Mikro $\left(X_{3}\right)$ secara parsial memiliki pengaruh nyata terhadap Kinerja Usaha Tani (Y).

4. Untuk peubah Penilaian Terhadap Pendampingan $\left(\mathrm{X}_{4}\right)$ diperoleh nilai $\mathrm{t}$ hitung $(2,687)>\mathrm{t}$ tabel $(1,99)$, Ho ditolak, maka Penilaian terhadap Pendampingan $\left(\mathrm{X}_{4}\right)$ secara parsial memiliki pengaruh nyata terhadap Kinerja Usaha Tani $(\mathrm{Y})$.

\section{Analisis Korelasi Berganda dan Koefisien Determinasi}

Untuk mengetahui hubungan secara bersama-sama antara campus comunity terhadap loyalitas $p$ digunakan analisis korelasi linear berganda (R). Berdasarkan hasil output software SPSS, diperoleh nilai koefisien korelasi (R) 0,805. Hal ini menunjukkan terdapat hubungan sangat kuat Kesesuaian Perencanaan dengan Kegiatan
Usahatani, Pengembangan Agribisnis Perdesaan, Pengembangan Keuangan Mikro dan Penilaian terhadap Pendampingan dengan Kinerja Usaha Tani. Koefisien determinasi $64,8 \%$ menunjukkan Kesesuaian Perencanaan dengan Kegiatan Usahatani, Pengembangan Agribisnis Perdesaan, Pengembangan Keuangan Mikro dan Penilaian Terhadap Pendampingan terhadap Kinerja Usaha Tani $64,8 \%$ dan sisanya 35,2\% merupakan kontribusi peubah lain diluar hal yang diteliti.

Selanjutnya menganalisis korelasi parsial yang digunakan untuk mengetahui seberapa besar hubungan masing-masing peubah bebas dengan peubah tidak bebas. Besarnya masingmasing pengaruh Kesesuaian Perencanaan dengan Kegiatan Usahatani, Pengembangan Agribisnis Perdesaan, Pengembangan Keuangan Mikro dan Penilaian Pendampingan terhadap kinerja usahatani dapat dilihat pada Tabel 13.

Korelasi parsial diperoleh dengan mengalikan standardized coefficient beta dengan zeroorder. Berdasarkan perhitungan tersebut di atas, maka besarnya pengaruh kesesuaian perencanaan dengan kegiatan usahatani $\left(X_{1}\right)$ terhadap kinerja usaha tani $21,9 \%$, maka besarnya kontribusi kesesuaian perencanaan dengan kegiatan usahatani $\left(X_{1}\right)$ berpengaruh secara parsial dan langsung mempengaruhi kinerja usahatani $(\mathrm{Y})$ $21,9 \%$. Besarnya pengaruh pengembangan agribisnis perdesaan $\left(\mathrm{X}_{2}\right)$ terhadap kinerja usahatani $13,1 \%$, maka besarnya kontribusi pengembangan agribisnis perdesaan $\left(\mathrm{X}_{2}\right)$ berpengaruh secara parsial dan langsung mempengaruhi kinerja usahatani $(Y)$ 13,1\%.

Besarnya pengaruh pengembangan keuangan mikro $\left(X_{3}\right)$ terhadap kinerja usahatani $14,9 \%$, maka besarnya kontribusi pengembangan keuangan mikro $(\mathrm{X} 3)$ berpengaruh secara parsial dan langsung mempengaruhi kinerja usaha tani (Y) 14,9\%. Besarnya pengaruh penilaian terhadap pendampingan $\left(\mathrm{X}_{4}\right)$ terhadap kinerja usahatani $14,8 \%$, maka besarnya kontribusi penilaian terhadap pendampingan $\left(\mathrm{X}_{4}\right)$ berpengaruh secara parsial langsung mempengaruhi kinerja usahatani (Y) $14,8 \%$.

Berdasarkan penjelasan di atas, secara total keseluruhan pengaruh kesesuaian perencanaan dengan kegiatan usahatani $\left(X_{1}\right)$, pengembangan agribisnis perdesaan $\left(X_{2}\right)$, pengembangan keuangan mikro $\left(X_{3}\right)$, penilaian terhadap pendampingan $\left(\mathrm{X}_{4}\right)$ terhadap kinerja usaha tani (Y) secara bersama-sama $64,8 \%$. Hal ini sesuai dengan koefisien determinasinya.

Tabel 12. Hasil Uji t

\begin{tabular}{ccccccc}
\hline Peubah & t hitung & Df & t tabel & Sig & Keterangan & Kesimpulan \\
\hline X1 & 4,278 & & & 0,000 & Ho ditolak & Nyata \\
X2 & 3,245 & & & 0,002 & Ho ditolak & Nyata \\
X3 & 4,081 & 81 & $\pm 1,99$ & 0,000 & Ho ditolak & Nyata \\
X4 & 2,687 & & & 0,009 & Ho ditolak & Nyata \\
\hline
\end{tabular}


Tabel 13. Korelasi parsial peubah $X$ terhadap $Y$

\begin{tabular}{ccccc}
\hline Peubah & $\begin{array}{c}\text { Standardized } \\
\text { Coefficients }\end{array}$ & $\begin{array}{c}\text { Correlations } \\
\text { Zero-order }\end{array}$ & $\begin{array}{c}\text { Besarnya } \\
\text { Pengaruh Secara } \\
\text { Parsial }\end{array}$ & $\begin{array}{c}\text { Besarnya } \\
\text { Pengaruh Secara } \\
\text { Parsial (\%) }\end{array}$ \\
\hline $\mathrm{X}_{1}$ & 0,343 & 0,639 & 0,219 & 21,9 \\
$\mathrm{X}_{2}$ & 0,245 & 0,536 & 0,131 & 13,1 \\
$\mathrm{X}_{3}$ & 0,290 & 0,514 & 0,149 & 14,9 \\
$\mathrm{X}_{4}$ & 0,232 & 0,639 & 0,148 & 14,8 \\
& Pengaruh Total & & 0,647 & 64,8 \\
\hline
\end{tabular}

Berdasarkan akumulasi jawaban anggota Gapoktan terhadap 10 (sepuluh) item pertanyaan diperoleh nilai 3.367 atau $78,30 \%$ dari 4.300 sebagai skor ideal. Hal ini menunjukkan kesesuaian perencanaan dengan pelaksanaan kegiatan usaha tani para anggota kelompok gapoktan penerima bantuan PUAP di Kabupaten Lampung Selatan, berarti pada umumnya kelompok tani telah mengetahui tujuan dari adanya bantuan PUAP tersebut. Dalam pelaksanaannya anggota kelompok telah memanfaatkan bantuan tersebut dalam bidang usaha agribisnis pertanian, sesuai dengan perencanaan sebelumnya.

Berdasarkan akumulasi jawaban responden terhadap 10 (sepuluh) item pertanyaan diperoleh nilai 2998 atau $69,72 \%$ dari 4300 sebagai skor ideal. Hal ini menunjukkan bahwa pengembangan agribisnis perdesaan bagi para anggota kelompok Gapoktan penerima bantuan PUAP di Kabupaten Lampung Selatan pada umumnya telah mampu untuk memberikan jaminan keberlangsungan usaha dan meningkatkan hasil produksi petani. Dengan adanya PUAP, maka sebagian besar petani telah mampu meningkatkan modal usaha anggota terutama yang bergerak di bidang perdagangan saprodi. Demikan pula halnya dengan usaha anggota kelompok di bidang pengolahan hasil pertanian, telah mampu memberikan nilai tambah bagi anggota kelompok Gapoktan.

Berdasarkan akumulasi jawaban terhadap 10 (sepuluh) item pertanyaan diperoleh nilai 3.244 atau $75,44 \%$ dari 4.300 sebagai skor. Hal ini menunjukkan bahwa dari pengembangan keuangan mikro pada kelompok gapoktan penerima bantuan PUAP di Kabupaten Lampung Selatan pada umumnya telah terjadi peningkatan modal kelompok dan berjalannya usaha simpan pinjam kelompok sebagai cikal bakal tumbuhnya lembaga keuangan mikro agribisnis.

Berdasarkan akumulasi jawaban terhadap 10 (sepuluh) item pertanyaan diperoleh nilai 3.313 atau $77,05 \%$ dari 4.300 sebagai skor ideal. Hal ini berarti bahwa pendampingan pada gapoktan penerima bantuan PUAP di Kabupaten Lampung Selatan pada umumnya dinilai cukup tinggi, karena dilakukannya sosialisasi, serta pembinaan yang intensif oleh Penyuluh Pendamping dan Penyelia Mitra Tani kepada Gapoktan penerima PUAP

Berdasarkan hasil kajian yang telah dilakukan, dapat disimpulkan bahwa kesesuaian perencanaan dengan pelaksanaan kegiatan usaha tani, pengembangan agribisnis perdesaan, pengembangan keuangan mikro, penilaian terhadap pendampingan berpengaruh secara keseluruhan terhadap kinerja usahatani pada Gapoktan penerima bantuan PUAP di Kabupaten Lampung Selatan, dan besarnya pengaruh kesesuaian perencanaan dengan pelaksanaan kegiatan usahatani $\left(X_{1}\right)$, pengembangan agribisnis perdesaan $\left(X_{2}\right)$, pengembangan keuangan mikro $\left(X_{3}\right)$, penilaian terhadap pendampingan $\left(X_{4}\right)$ terhadap kinerja usaha tani $(Y) 64,8 \%$.

Berdasarkan perhitungan statistik diperoleh besarnya pengaruh kesesuaian perencanaan dengan pelaksanaan kegiatan usaha tani $\left(X_{1}\right)$ terhadap kinerja usaha tani $21,9 \%$, maka besarnya kontribusi kesesuaian perencanaan dengan pelaksanaan kegiatan usahatani $\left(X_{1}\right)$ berpengaruh secara parsial langsung mempengaruhi kinerja usaha tani (Y) 21,9\%. Hasil ini menunjukkan kesesuaian perencanaan dengan pelaksanaan kegiatan usaha tani berpengaruh secara parsial terhadap kinerja usaha tani pada Gapoktan penerima bantuan PUAP di Kabupaten Lampung Selatan. Hal ini menjelaskan bahwa semakin sesuai pelaksanaan kegiatan terhadap perencanaan yang telah dibuat akan menyebabkan semakin tingginya kinerja usaha tani Gapoktan.

Berdasarkan perhitungan statistik diperoleh besarnya pengaruh pengembangan agribisnis perdesaan $\left(X_{2}\right)$ terhadap kinerja usahatani $13,1 \%$, maka besarnya kontribusi pengembangan agribisnis perdesaan $\left(X_{2}\right)$ berpengaruh secara parsial langsung mempengaruhi kinerja usahatani $(\mathrm{Y})$ $13,1 \%$.

Hasil ini menunjukkan pengembangan agribisnis perdesaan berpengaruh secara parsial terhadap kinerja usahatani pada Gapoktan penerima bantuan PUAP di Kabupaten Lampung Selatan. Hal ini menjelaskan bahwa semakin berkembangnya usaha agribisnis anggota kelompok, ditandai dengan peningkatan hasil produksi, munculnya diversifikasi produk pengolahan hasil pertanian yang memberikan nilai tambah bagi petani, yang ditunjukkan oleh kinerja usahatani semakin baik dan meningkat.

Berdasarkan perhitungan statistik diperoleh besarnya pengaruh pengembangan keuangan mikro $\left(X_{3}\right)$ terhadap kinerja usahatani adalah $14,9 \%$, maka besarnya kontribusi pengembangan keuangan mikro $\left(X_{3}\right)$ berpengaruh secara parsial langsung mempengaruhi kinerja usahatani $(\mathrm{Y})$ 14,9\%. Hasil ini menunjukkan pengembangan 
keuangan mikro berpengaruh secara parsial terhadap kinerja usaha tani pada Gapoktan penerima bantuan PUAP di Kabupaten Lampung Selatan. Munculnya lembaga keuangan mikro dalam bentuk usaha simpan pinjam sederhana yang dikelola oleh anggota kelompok sendiri sebagai upaya untuk pemenuhan ketersediaan modal bagi anggotanya untuk menandakan kinerja usaha dari Gapoktan penerima PUAP telah semakin baik dan meningkat.

Berdasarkan perhitungan statistik diperoleh besarnya pengaruh penilaian terhadap pendampingan $\left(X_{4}\right)$ terhadap kinerja usahatani $14,8 \%$. Dengan demikian dapat disimpulkan bahwa besarnya kontribusi penilaian terhadap pendampingan $\left(\mathrm{X}_{4}\right)$ berpengaruh secara parsial langsung mempengaruhi kinerja usahatani (Y) adalah $14,8 \%$. Hasil ini menunjukkan bahwa penilaian terhadap pendampingan berpengaruh secara parsial terhadap kinerja usaha tani pada Gapoktan penerima bantuan PUAP di Kabupaten Lampung Selatan. Dari hasil kajian ini dapat dinyatakan bahwa semakin baik dan berperan aktifnya Penyuluh Pendamping, serta PMT dalam melakukan sosialisasi serta pembinaan terhadap kelompok/Gapoktan binaannya, akan memberikan dampak meningkatnya kinerja usahatani Gapok$\tan$.

\section{KESIMPULAN}

Kesesuaian perencanaan dengan pelaksanaan kegiatan usaha tani, pengembangan agribisnis perdesaan, pengembangan keuangan mikro, serta penilaian terhadap pendampingan memberikan pengaruh nyata secara simultan terhadap kinerja usaha tani di Kabupaten Lampung Selatan $64,8 \%$ dan sisanya (35,2\%) dipengaruhi oleh faktor-faktor lain yang tidak diteliti. Hal tersebut ditandai dengan: dimanfaatkannya bantuan modal untuk usaha di bidang pertanian sesuai dengan perencanaan yang telah dibuat; meningkatnya hasil produktivitas pertanian tanaman pangan (padi), terjadinya peningkatan modal untuk anggota di bidang perdagangan saprodi, munculnya bidang usaha pengolahan hasil produksi pertanian seperti kripik pisang dan singkong; pemupukan modal kelompok, terutama untuk simpan pinjam; memberikan sosialisasi dan pembinaan kepada kelompok tani/Gapoktan, terutama dalam administrasi yang lebih baik; ditemui beberapa permasalahan yang terjadi, antara lain belum seluruh anggota kelompok mendapatkan bantuan permodalan, masih adanya tunggakan pinjaman anggota kelompok yang melewati batas waktu perjanjian dengan kelompoknya, laporan perkembangan kegiatan belum dibuat oleh Gapoktan maupun PMT secara tertib setiap bulannya yang harus dilaporkan kepada Direktorat Pembiayaan, dan PMT belum memfasilitasi kemitraan usaha dengan pelaku agribisnis.

\section{DAFTAR PUSTAKA}

[BPS] Badan Pusat Statistik Kabupaten Lampung Selatan. 2010a. Statistik Daerah Kabupaten Lampung Selatan 2010. Kalianda.

2010b. Lampung Selatan dalam Angka, Lampung Selatan In Figures 2010. Kalianda

Indriantoro, N dan Supomo, B. 2002. Metodologi Penelitian Bisnis Untuk Akuntansi dan Manajemen, Edisi Pertama, BPFEYogyakarta

Kaplan, M. R, dan Saccuzzo, P. D, 1993. Phsycological Testing Principles, Application, and Issues; Brooks/Cole Publishing Company, Pacific Grove. California

Pusat Pembiayaan. 2009. Laporan Monitoring dan Evaluasi Pengembangan Usaha Agribisnis Perdesaan (PUAP). Kementerian Pertanian. Jakarta

2010. Laporan Monitoring dan Evaluasi Pelaksanaan Program Pengembangan Usaha Agribisnis Perdesaan (PUAP) Tahun 2008-2009, Kementerian Pertanian, Jakarta

Riduwan dan Kuncoro, E.A. 2008. Cara Menggunakan dan Memaknai Analisis Jalur (Path Analysis), CV.Alfabeta. Bandung

Syahyuti. 2008. Strategi dan Tantangan dalam Pengembangan Gabungan Kelompok Tani (Gapoktan) sebagai Kelembagaan Ekonomi di Pedesaan. Pusat Analisis Sosial Ekonomi dan Kebijakan Pertanian. Bogor

Umar, H. 2008. Desain Penelitian Akuntansi Keperilakuan, Raja Grafindo Persada. Jakarta 